\title{
Use of space and temporal distribution of Trichechus manatus manatus Linnaeus in the region of Sagi, Rio Grande do Norte State, Brazil (Sirenia, Trichechidae)
}

\author{
Danielle Paludo ${ }^{1}$ \\ Alfredo Langguth ${ }^{2}$
}

\begin{abstract}
The marine manatee Trichechus manatus manatus Linnaeus, 1758 is endangered in the Brazilian Atlantic coast due to indiscriminate hunting practiced in the past, and to the low reproductive rate of the species. This work studies its use of space and temporal occurrence in the coastal area of Sagi, Northeastem Brazil. Daily observations from the beach of the animals in the sea were made during daytime from 1990 through 1993. The presence of reefs covered with marine algae is a determinant factor in the occurrence of the manatee. They were sighted feeding on algae that grow over the reefs close to beaches that were of high energy during high tide. The range used by manatees shifted according to tide. They occur in depths of 0.4 to $3.8 \mathrm{~m}$; the distance from the beach varies according to the tide level. They show marked seasonality of occurrence, with higher frequencies in December - January and lowest in June - July. Two possible causes of the seasonal occurrence are discussed. Sagi is important for the conservation of the species in Northeastern Brazil as feeding and reproductive grounds.

KEY WORDS. Sirenia, Trichechus manatus manatus, manatee, temporal distribution, Northeastem Brazil, ecology
\end{abstract}

Historically, the manatee Trichechus manatus manatus Linnaeus, 1758 was distributed from the Caribe down to the coast of Espírito Santo State in Southeastern Brazil (WHITEHEAD 1978). In a survey of the distribution of the species, LIMA et al. (1992) considered that the area of occurrence and the number of T. m. manatus decreased a great deal in comparison to those mentioned by C. Albuquerque and G. M. Marcovaldi in an unpublished report, ten years before. These authors registered its disappearance in the State of Sergipe, being Pontal do Peba, in the State of Alagoas, the current Southern limit. The distribution of T. m. manatus along the Brazilian coast is discontinuous, because the manatee is not found in the Southern coast of Pernambuco State and in part of the coast of Ceará State (LiMA et al. 1992). Therefore, three areas of occurrence can be defined along the Brazilian coast: the first, from the River Oiapoque to the beach of Cacimbinhas, in municipality of Guriú, Ceará State; the second, from Barro Preto, Iguape, South of the city of Fortaleza, Ceará State, to Olinda, Pernambuco State; and the third area, from Tamandaré, Pernambuco State, to Pontal do Peba, in the mouth of the Rio São Francisco, Alagoas State.

1) Centro Nacional de Conservação e Manejo de Sirênios, IBAMA. Estrada do Forte Orange, Caixa Postal 01, 53900-000 Ilha de Itamaracá, Pernambuco, Brasil.

2) Departamento de Sistemática e Ecologia, Universidade Federal da Paraiba. Campus Universitário, 58059900 João Pessoa, Paraiba, Brasil. E-mail: alfredo@ dse.ufpb.br 
Trichechus manatus manatus is an endangered species in Brazil due to former indiscriminate hunting for its meat, fat and hide, also to its low reproductive rate. For this reason Brazil's government (IBAMA) has sponsored since 1980 the Projeto Peixe-Boi, an effort in favor of the research and conservation of the species. A survey made by the Projeto Peixe-Boi identified the coastal area of Sagi, Rio Grande do Norte State, as priority for actions, due to the higher concentration of $T$. m. manatus as well as the presence of feeding grounds and reproductive activities of the animals. This study will focus on the Sagi region, a 16 kilometers sea coastal range between the city of Baía Formosa (6 $\left.6^{\circ} 36^{\prime} 11^{\prime \prime} \mathrm{S}, 34^{\circ} 57^{\prime} 54^{\prime \prime} \mathrm{W}\right)$ in Rio Grande do Norte and the mouth of the Rio Camaratuba (6 $\left.22^{\prime} 55^{\prime \prime} \mathrm{S}, 34^{\circ} 59^{\prime} 31^{\prime \prime} \mathrm{W}\right)$ in Paraíba but most information was gathered between the points of João Santo and Bóia (Fig. 1).

The purpose was to learn about the use of space and temporal occurrence of T. m. manatus in the coastal region of Sagi, and to discuss the factors determining this occurrence. The relationship between the distribution of the animals and the tides was also studied.

\section{MATERIAL AND METHODS}

Use of Space. To observe the manatee, the beach was regularly traveled on foot, and the sea was scanned daily with the aid of binoculars, only during daytime, with an interruption of two hours for lunch, from January 1990 through December 1993. This resulted in a total observation effort of 6.737 hours. The trips used to start at the village of Sagi, and follow northwards, up to the point called João Santo or southwards down to the point Bóia (Fig. 1). Once the manatee was located, the observer stayed at the observation place until the animals became out of view. At the beginning Danielle Paludo recorded the sightings but from the 6th month on, a fisherman, properly trained accomplished the observations. The following data were recorded on a form: time of begin of searching, time of the first sighting, number of young and adults, place of the sighting and time of ending the work..

Frequencies of groups sighting in each place were calculated, computing the presence of a group at the place only once a day. As the probability of observing the manatees in a certain place depends on the number of days that this place has been visited, i. e. on the observation effort at the place, and as the number of days was not equal in all the places, the absolute frequencies of groups sighting was corrected, dividing them by the accomplished effort and multiplying by 100 , obtaining the place's corrected frequency of sighting of manatee groups (FGS).

Knowing the preference of the animals for certain places through the FGS, it was looked for a correlation of the occurrence with the habitat characteristics, such as depth of water, substratum, hydrodynamic and food availability.

The depth of the water at the places of occurrence was measured during tides 0.0 with the aid of a graduated rope having a weight at the end. Starting from this measurement, the maximum and minimum possible values were calculated according to the tide table for the harbor of Cabedelo. To determine the depth of the water at the place and time of sighting, it was proceeded as follows: the level of the tide at the time of sighting was read in the tide table for the harbor of Cabedelo, published by the "Diretoria de Hidrografia e Navegação" (DHN) for the years of 1990, 1991,

Revta bras.Zool. 19 (1): $205-215,2002$ 
1992 and 1993. To this value, it was added the depth measured, at the place, during the 0.0 tide. A delay in reaching the lowest tide level was observed between Cabedelo and the study area. The sea lowered in our area $0.3 \mathrm{~m}$ after the 0.0 tide for Cabedelo was reached.

In order to get additional data, fishermen were interviewed on the occurrence of manatee in the area.

Temporal occurrence. To study the temporal occurrence of manatees, it was used the monthly frequency of individual sightings (FIS) FIS $=\Sigma\left(S_{M} / D_{M}\right) 100$. At each place the monthly number of sigthings $\left(S_{M}\right)$ was corrected for the number of days of observation ( $\left.D_{M}\right)$ the FIS was obtained by adding this corrected values of all places.

\section{RESULTS}

\section{Characteristics of the Area}

Presence of reefs with algae. All the sighting places of the manatees have reefs covered with marine algae, which are part of a discontinuous line of sandstone and coralline reefs of coastal origin, disposed parallel to the beach all over the region of Sagi. Its distance from the beach varies between $0 \mathrm{~m}$ and $50 \mathrm{~m}$ in the low tide, when they are exposed. During the high tide they are submerged except for few points. These reefs are classified as "fringe reefs" - that are contiguous to the beach and have no "sailing channel" or "inner sea"of sandy ground. The reefs offer a favorable substratum for the algae to growth, which are extremely abundant.

The points Roncador, Rachada and Bóia have reef formations practically continuous in the meso and infra littoral regions(Fig. 1). Parts of these reefs are almost always emergent and the submerged part is densely covered with marine algae. The plateau and the whole external face of the reefs are submitted to strong impact of the waves. The algae are more abundant in these three places than in the others visited by the manatee. During high tide, from Rachada to Bóia, a pool of shallow water is formed between the beach and the reefs, communicating with the open sea (Fig. 2). In Araújo and Inácio, the sea floor is formed by reef- plateaus that are exposed only at very low tides, all of them in the infra-littoral region. In Pedra Derradeira, the reefs are irregularly distributed at the meso and infra littoral regions. The mouth of the river Guajú, opens to the North and the algae grow in the reef facing the river, as well as in the whole external face and on the plateau of the reefs. To the South was found the reefs of Roncador. In Cutia, the reefs form two flat plateaus, with small declivity, and presenting a great diversity and abundance of marine algae. Between the plateaus, at low tide, it is formed a pool of shallow water of about $500 \mathrm{~m}$ of extension (Fig. 2). Guajirú is located at the mouth of the Riacho Taboquinha. It presents discontinuous and smaller reefs, predominantly colonized by green algae next to the mouth of the stream, and by red algae in its deepest part. In Urubu and João Santo the reefs range from the supra littoral to infra littoral, exposed in a large extension even during the highest tides. 


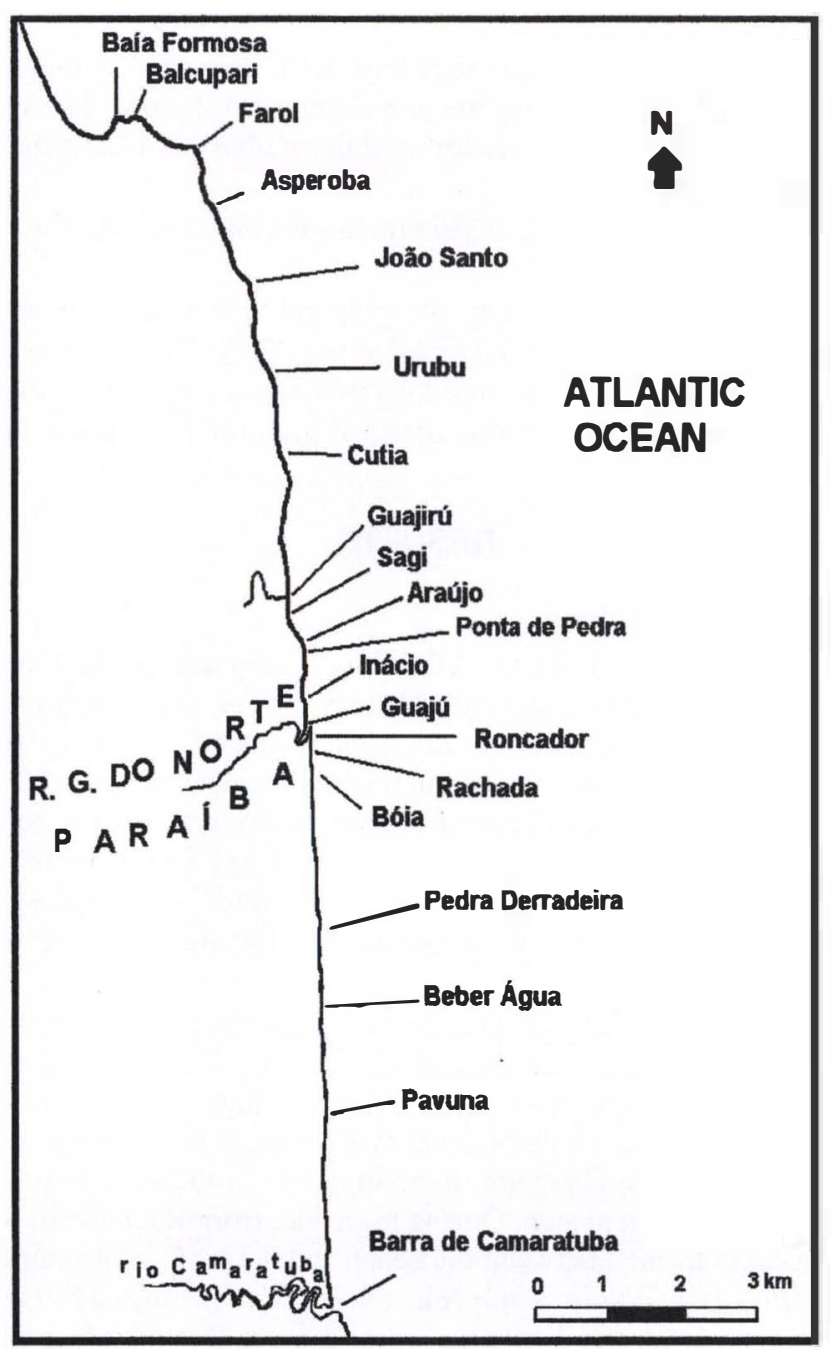

Fig. 1. Map of the region of Sagi showing the places of occurrence of the manatee.

Fresh water. The salinity in this region varies annually between 28 and $36 \%$ o (LiMA et al. 1992). The superficial temperature of the water registered between the years of 1990 and 1993 varied from 23 to $31^{\circ} \mathrm{C}$. The rainy season in Sagiextends from April to June and the average annual rainfall in this area lies between 1250 and 1500 mm (NIMER 1989). Three water courses flow in the study area, and may contribute during the rainy season to lower de salinity of the neighbor sea. They are the Riacho Taboquinha, of small size, the Rio Guajú, a river of medium to small size and farther South the RioCamaratuba, the largest in the region. The last two havetypical mangrove vegetation, and enough depth to allow the entrance of the manatee in their estuary. 

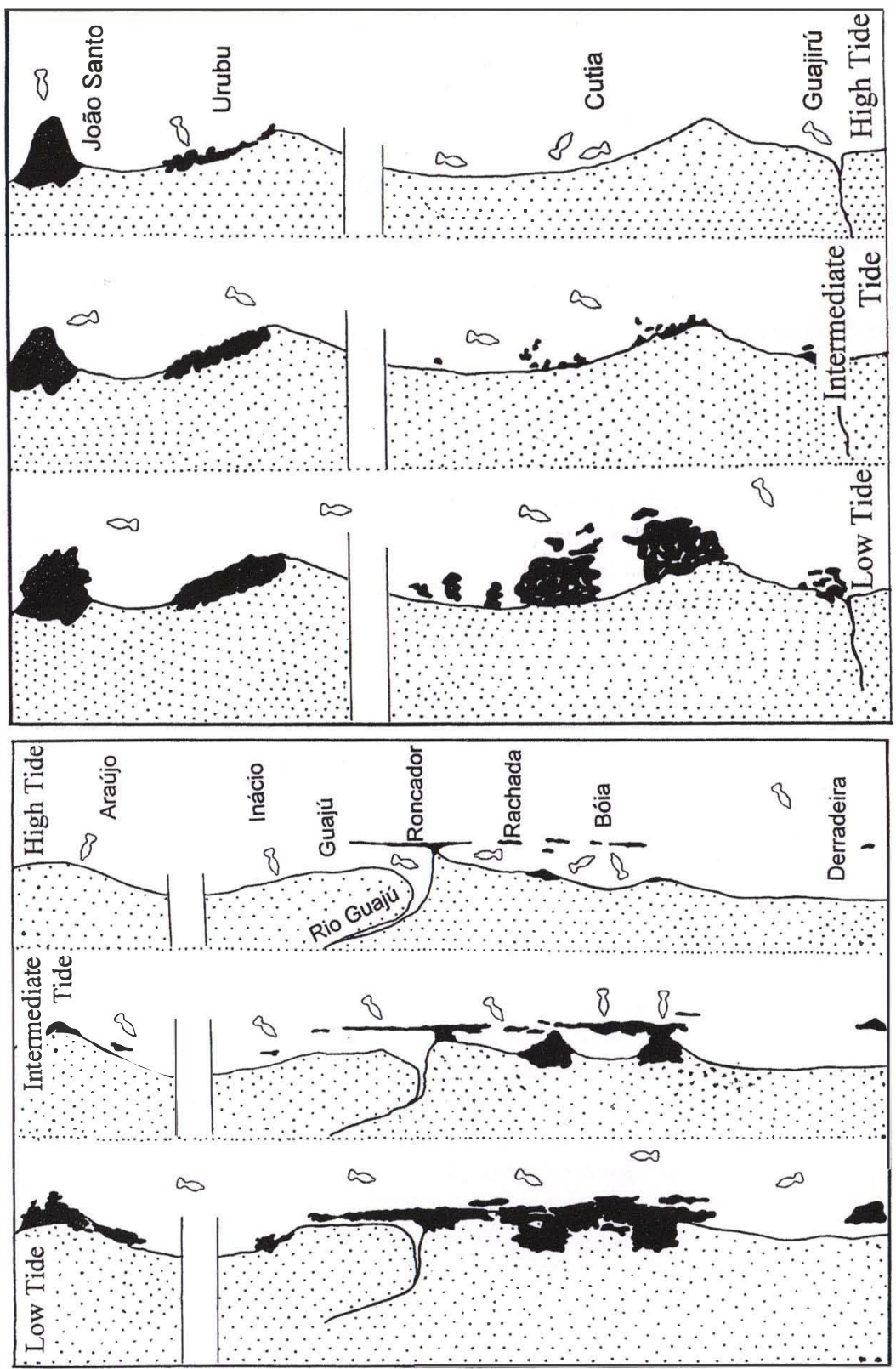

Fig. 2. Schematic drawing of the coast showing the positions of the manatees in the places Araújo, Inácio, Guajú, Roncador, Rachada, Bóia, Derradeira, Joāo Santo, Urubu, Cutia and Guajiru during three tide levels. The animals approach the beach as the tide advances, having access to the banks of algae in shallow water, to the Barra of Rio Guajú and to the "pools" formed between Roncador and Bóia, and in Cutia during high tide. $1 \mathrm{~km}=25 \mathrm{~mm}$ approximately. 
Hydrodynamics. The beaches of Sagi are of high energy with strong breakers, especially at high tide. Frequently sighted in the breaking area, the animals show great domain of their body, which is maintained at place. In this area, they elevate the head out of the water, more than usual, in order to breathe. Breakers are present at all places where manatees were observed, except in the mouth of Rio Guajú. The beaches of the region are seldom frequented by people and except in Baía Formosa and Barra de Camaratuba, they have strong waves, not allowing the transit of motor boats close to the shore.

\section{Use of Space}

Observations were made during an average daily period of 6.7 hours. The whole observation effort totalised 6.737 hours with a monthly mean of 142 hours. In the first four years, the work was interrupted in approximately $6 \%$ of the total foreseen days, due to holidays or to the observer's personal impossibility to work. In June 1993, there was a continuous 30 days interruption in the collection of data.

Twelve points of occurrence of the manatee were identified in the studied area (Fig. 1). Another seven places - Pavuna, Beber Água, Asperoba, Farol, Baía Formosa, Barra de Camaratuba and Balcupari -were indicated by fishermen as occurrence points, though the presence of manatee was not confirmed with sightings. Sagi was the starting point of the courses, however there were no sightings in that place. Manatees occurred in groups up to six animals, some of them formed by females accompanied by their calves. Table I summarizes the observations made in the area of Sagi from 1990 through 1993.

Higher frequencies of group sighting (FGS) were found at Cutia, Bóia, Araújo, João Santo and Rachada (Tab. II). Cutia and Bóia, have reefs densely colonized by algae, and during high tides, have areas of quite water that favors resting, after feeding (Fig. 2). Araújo and João Santo possess large banks of algae that are rarely out of reach for the manatee, even in the lowest tides.

Between the points where the manatees were sighted the coastal sea floor is sandy with low density of algae and reefs are absent. Although the animals certainly crosses these areas, they were never observed foraging or staying there.

Depth, tides and occurrence. In the area of study the manatee occurs very close to the beach ( 5 to $30 \mathrm{~m}$ from the edge of the water), and were seen in such shallow places that the water hardly covers the body of the animal. In the places where the animals were observed the depth varies between $0.00 \mathrm{~m}$ and $1.20 \mathrm{~m}$ during the $0.0 \mathrm{~m}$ tide (Tab. III). Considering the amplitude of tides in the area up to $2.6 \mathrm{~m}$, the maximum calculated depth was found in Bóia, $3.80 \mathrm{~m}$.

The behavior of "walking", i. e., of dragging themselves using the pectoral fins was frequently observed, during their displacement in very shallow areas of Sagi. This kind of locomotion is reported also by the fishermen of the Northern coast of the State of Amapá, where they localize the manatees by the traces left on the mud during the low tides (Personal communication of workers of the Projeto Peixe-Boi). Stranding of adult manatee was not observed in Sagi.

Since in this region the variation of tide is the main factor determining the depth of water and, as the studied places are open systems, the tidal variation provokes a retraction or advance of the range used by the manatee, across the 
shoreline, offering different habitats according to tide. For instance, in Bóia and Cutia, between the beach and the reefs, an area of shallow water protected from breakers is formed during the intermediary and high tides. In these places lone animals and females with young were sighted, after having fed themselves on the external side of the reefs. Seemingly, between a feeding session and another at the reefs, the manatees enter in these "pools" to rest. Thus, sightings in Cutia, Araújo, Derradeira, Inácio, Roncador, Rachada and Bóia occurred in different tide classes, the sighting points varying in distance from the tidehead (Fig. 2).

Table I. Manatee sightings made between João Santo and Bóia, period 1990 to 1993.

\begin{tabular}{|c|c|c|c|c|c|c|c|}
\hline Year & Month & $\begin{array}{c}\text { Number of } \\
\text { observation days }\end{array}$ & $\begin{array}{l}\text { Number of } \\
\text { sightings }\end{array}$ & FGS & $\begin{array}{l}\text { Number of } \\
\text { adults }\end{array}$ & $\begin{array}{l}\text { Number } \\
\text { of young }\end{array}$ & $\begin{array}{c}\text { Size of } \\
\text { largest group }\end{array}$ \\
\hline \multirow{12}{*}{1990} & January & 23 & 9 & 38 & 12 & 3 & 3 \\
\hline & February & 21 & 11 & 52 & 13 & 2 & 3 \\
\hline & March & 22 & 8 & 36 & 9 & 0 & 2 \\
\hline & April & 19 & 7 & 37 & 9 & 1 & 2 \\
\hline & May & 22 & 7 & 32 & 7 & 2 & 2 \\
\hline & June & 17 & 3 & 18 & 3 & 0 & 1 \\
\hline & July & 21 & 6 & 29 & 7 & 0 & 2 \\
\hline & August & 20 & 4 & 20 & 4 & 1 & 2 \\
\hline & September & 21 & 10 & 48 & 12 & 4 & 3 \\
\hline & October & 22 & 9 & 41 & 17 & 4 & 3 \\
\hline & November & 20 & 11 & 55 & 18 & 4 & 5 \\
\hline & December & 20 & 12 & 60 & 20 & 3 & 4 \\
\hline \multirow{12}{*}{1991} & January & 23 & 15 & 65 & 41 & 11 & 6 \\
\hline & February & 21 & 13 & 62 & 29 & 6 & 4 \\
\hline & March & 20 & 10 & 50 & 13 & 3 & 3 \\
\hline & April & 23 & 5 & 22 & 5 & 0 & 1 \\
\hline & May & 22 & 2 & 9 & 3 & 0 & 2 \\
\hline & June & 18 & 0 & 0 & 0 & 0 & 0 \\
\hline & July & 22 & 3 & 14 & 3 & 1 & 2 \\
\hline & August & 22 & 2 & 9 & 3 & 0 & 2 \\
\hline & September & 21 & 4 & 19 & 5 & 2 & 2 \\
\hline & October & 24 & 10 & 42 & 15 & 8 & 4 \\
\hline & November & 20 & 14 & 70 & 34 & 11 & 5 \\
\hline & December & 23 & 19 & 83 & 36 & 12 & 6 \\
\hline \multirow{12}{*}{1992} & January & 22 & 15 & 68 & 32 & 10 & 4 \\
\hline & February & 19 & 4 & 21 & 5 & 0 & 2 \\
\hline & March & 21 & 4 & 19 & 4 & 1 & 2 \\
\hline & April & 20 & 3 & 15 & 3 & 0 & 1 \\
\hline & May & 21 & 4 & 19 & 6 & 1 & 2 \\
\hline & June & 19 & 2 & 10 & 2 & 1 & 2 \\
\hline & July & 22 & 4 & 18 & 4 & 0 & 1 \\
\hline & August & 21 & 5 & 24 & 7 & 2 & 3 \\
\hline & September & 20 & 5 & 25 & 10 & 2 & 4 \\
\hline & October & 22 & 13 & 59 & 30 & 7 & 4 \\
\hline & November & 20 & 11 & 55 & 21 & 3 & 4 \\
\hline & December & 24 & 16 & 67 & 31 & 6 & 4 \\
\hline \multirow[t]{13}{*}{1993} & January & 20 & 12 & 60 & 21 & 3 & 3 \\
\hline & February & 18 & 10 & 56 & 16 & 2 & 3 \\
\hline & March & 25 & 14 & 56 & 26 & 6 & 5 \\
\hline & April & 19 & 6 & 32 & 8 & 1 & 2 \\
\hline & May & 21 & 5 & 24 & 6 & 1 & 2 \\
\hline & June & 0 & 0 & - & - & - & - \\
\hline & July & 22 & 1 & 4 & 1 & 1 & 2 \\
\hline & August & 23 & 10 & 43 & 17 & 4 & 3 \\
\hline & September & 21 & 11 & 52 & 19 & 1 & 3 \\
\hline & October & 22 & 10 & 48 & 15 & 2 & 3 \\
\hline & November & 22 & 12 & 54 & 17 & 2 & 3 \\
\hline & December & 24 & 10 & 42 & 20 & 4 & 4 \\
\hline & Total & 994 & 381 & & 639 & 138 & \\
\hline
\end{tabular}


Table II. Places of occurrence of manatee in the region of Sagi and absolute and corrected frequencies of sighting (FGS). Period 1990 to1 1993.

\begin{tabular}{lccr}
\hline \multicolumn{1}{c}{ Place } & Number of days visited & Number of days with sightings & FGS \\
\hline João Santo & 115 & 13 & 11 \\
Urubu & 114 & 8 & 7 \\
Cutia & 275 & 36 & 13 \\
Guajiru & 294 & 8 & 2 \\
Araújo & 687 & 79 & 11 \\
Ponta de Pedra & 687 & 16 & 2 \\
Pedra derradeira & 541 & 15 & 2 \\
Inácio & 572 & 27 & 4 \\
Guajú & 506 & 15 & 2 \\
Roncador & 481 & 44 & 10 \\
Rachada & 372 & 39 & 12 \\
Bóia & 275 & 33 & \\
\hline
\end{tabular}

Table III. Minimum and maximum depths found in the places of manatee sighting. (*) Depths measured at $2.6 \mathrm{~m}$ tide, the others measured at tide $0.0 \mathrm{~m}$, and estimating the maximum depth from tide table.

\begin{tabular}{lcc}
\hline \multicolumn{1}{c}{ Place } & Depth at day of tide $0.0 \mathrm{~m}$ & Depth at day of tide $2.6 \mathrm{~m}$ \\
\hline Joåo Santo & 0.60 & 3.20 \\
Urubu & 0.70 & 3.30 \\
Cutia (outer side) & 0.60 & 3.20 \\
Guajirú & 0.50 & 3.10 \\
Araújo & 1.10 & 3.70 \\
Ponta da Pedra & 0.50 & 3.10 \\
Pedra derradeira & 1.00 & 3.60 \\
Bóia (outer side) & 1.20 & 3.80 \\
Bóia (inner side) & 0.00 & $1.60^{*}$ \\
Inácio & 0.20 & 2.80 \\
Guajú & 0.75 & 3.35 \\
Roncador (inner side) & 0.00 & 0.80 \\
Rachada & 1.00 & 3.60 \\
\hline
\end{tabular}

\section{Temporal occurrence}

There is a marked seasonality of occurrence of the animals in the studied area, the FIS rises in the summer months, December and January. In February, the number of animals begin to decrease gradually to minimum values in June-July, and beginning to rise again from July on (Fig. 3).

\section{DISCUSSION}

The presence of fringe reefs densely colonized by algae seems to be a decisive factor for the spatial distribution of manatees in the area of study. Their presence seems to be apparently related to the algae, mostly red algae, covering the reefs. The animals were never observed foraging or staying over sandy sea floor, with low density of algae as found between the sighting points. This agrees with CAldwell \& CALDWELl (1985) statement that manatees tend to congregate in certain areas where ecological conditions best suit their requirements.

A seasonal occurrence similar to that here reported was observed, although not so well documented, in Barra the Mamanguape, a place located approximately $30 \mathrm{Km}$ to the South of Sagi (SiLva et al. 1992). 


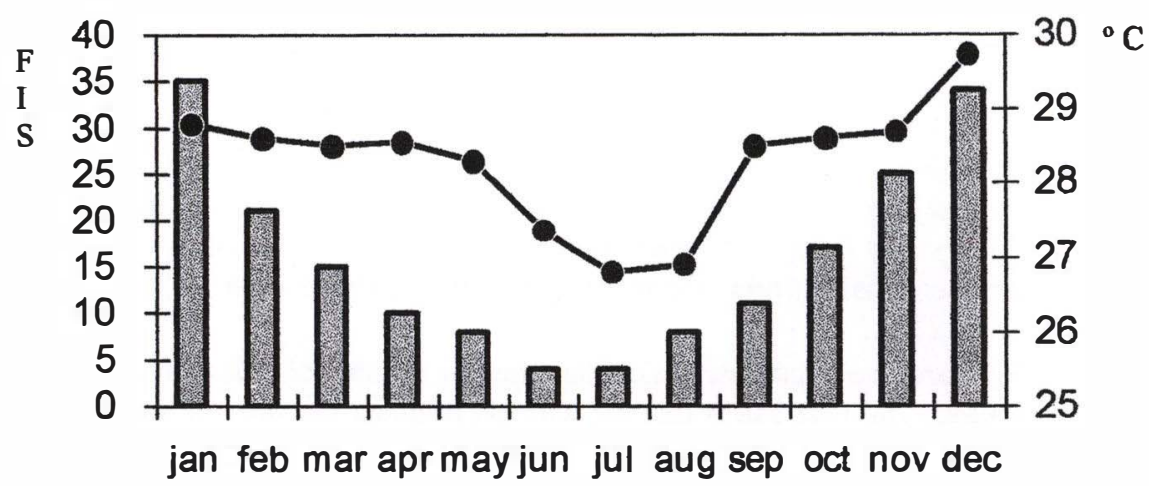

FIS -๑-Temperature

Fig. 3. Frequencies of Individual Sighting (FIS) and monthly averages of the superficial temperature of water in Sagi from 1990 to 1993.

In July the water becomes more turbid due to stronger Southeast winds. According to the fishermen, this is responsible for the absence of the manatees. There are, however, no indications that support this relation, since the manatees usually frequent areas of turbid waters, as found in the mangroves.

Possibly, the animals that frequent these areas move to the North, following the direction of the coastal currents. However, there are no records on the temporal distribution to the North of the studied area that could support this hypothesis. Nothing is known about possible movements of manatees along the Brazilian Coast except for the animal released and monitored in Alagoas (see below).

Ninety percent of the individuals of $T$. $m$. latirostris (Harlan, 1823) captured, marked and monitored by radio-satellite in Florida, make seasonal migrations, which go, typically, from the South, in the winter, to the Center-North of the peninsula, in the summer (CALDWELL \& CALDWELL 1985). The other $10 \%$ remain in the same area during the whole year. Distances up to $250 \mathrm{~km}$ traveled by these marked animals were recorded (ACKERMAN 1995; DEUTSCH et al. 1998), and the annual migratory circuit of the species in the hydrographic complex of the United States Atlantic Coast goes to $1.700 \mathrm{Km}$, reaching speeds up to 50 $\mathrm{km} /$ day (REID et al. 1991). The low metabolic rate and the caloric losses drive the animals into an energy stress, avoided by the migration or by their grouping in refuges of warm waters. In summer the animals disperse widely in Florida forming small groups, having low density and appearing in unexpected places (ACKERMAN 1995). They probably move away from the warm-water refuges because food availability in the winter range had been reduced. This is not the case in Sagi, since was did not observe any important seasonal variation of the algae cover of the reefs. In Surinam movements have been correlated with the rainy season (HUSAR 1978). 
The thermal variation in Florida can be wide (air temperatures from under $10^{\circ} \mathrm{C}$ to over $30^{\circ} \mathrm{C}$ ). The lowest limit of bearable temperature for manatees is around $20-21^{\circ} \mathrm{C}$ but these animals have been tracked in water at $15^{\circ} \mathrm{C}$ (HUSAR 1978, CALDWELl \& CALDWELl 1985). Variation of the air temperature induces manatee migrations (HARTMAN 1979). The annual variation of water temperature in our area of study is $23-31^{\circ} \mathrm{C}$ whereas in Blue Lagoon, Florida, water temperature varied seasonally from about $21^{\circ} \mathrm{C}$ in December to over $27^{\circ} \mathrm{C}$ in July (REYNOLDS 1981).

There are two hypotheses to explain the low number of manatees in Sagi at the wintertime. The first one is that the animals frequent this area in the summer and migrate to another place in the winter. This may be related to the decreasing of some degrees in the water temperature, associated to the increasing winds and coastal currents in direction to the North, favoring the manatee migration. The animals are rarely observed in the sea far from the coast during the winter, and the number of records of dead stranded animals at this time is small. These arguments are reinforced by the animals' capacity of traveling long distances, as they do along the coast of the United States.

In Brazil, the Projeto Peixe-Boi registered, by radio-telemetry tracking, a maximum displacement of $190 \mathrm{~km}$ made by a captive animal released in the State of Alagoas (Régis de Lima and Denise de Castro, pers. comm.). Transferring this distance to Sagi, the manatees would be able to move northwards up to the Northern limit of Rio Grande do Norte or southwards to the Northern limit of Alagoas. Using for calculation the distances traveled by Florida manatees, animals of Sagi could reach the coasts of Piauí State to the North and of the State of Bahia to the South. Since no increase in number during the winter has been recorded in Alagoas, if the manatees from Sagi migrate, they will probably move to the North to warmer waters.

Another hypothesis to explain the seasonality of occurrence of the manatee in Sagi is that they concentrate during the summer and, in winter, they disperse along the coast or in the open ocean. The main argument in favor of this hypothesis is that concentration of animals in the summer is necessary for the reproductive activities of mating and birth of young. The absence of great environmental variations in the area would allow the permanence of the animals during the whole year. When they disperse, their visualization becomes more difficult, apparently "disappearing", but in summer, when they concentrate in groups, they are easily sighted. In Florida, however, the animals migrate into the open ocean in the summer (CALDWELL \& CALDWELL 1985). Radio-telemetry studies will certainly settle this question in the future.

ACKNOWLEDGEMENTS. We thank all the workers of the Projeto Peixe-Boi, particularly José Carlos Leôncio, for providing field observations, and Eunice Maria Oliveira, Ricardo Soavinski and Régis Pinto de Lima from Centro Peixe-Boi/IBAMA for their kind support. We also thank Virginia Fernandes Fonseca for translation of the manuscript. This research was funded by Instituto Brasileiro do Meio Ambiente e dos Recursos Naturais Renováveis - IBAMA and is part of a Master Dissertation on Zoology at the Universidade Federal da Paraíba. Financial support was also provided by RIB (Rutilo e Ilmenita do Brasil). 


\section{REFERENCES}

ACKERMAN, B.B. 1995. Aerial surveys of manatees: a summary and progress report, p.13-34. In: T.J. O'Shea; B.B. Ackerman \& H.F. Percival (Eds). Population Biology of the Florida Manatee. Washington, D.C., National Biological Service Information and Technical Report 1, 320p.

CAldwell, D.K. \& M.C. CALDwell. 1985. Manatees, Trichechus manatus Linnaeus, 1758; Trichechus senegalensis Link, 1795 and Trichechus inunguis (Natterer, 1883), p. 33-66. In: S.H. RIDGWAY \& R.J. HARRISON (Eds). Handbook of marine mammals. London, Academic Press, Vol. 3, 362p.

DeUtsCh, C.J.; R.K. BondE \& J.P. ReID. 1998. Radio-tracking Manatees from land and space: tag design, implementation and lessons learned from long-term study. MTS Jour., Gainsville, 32 (I): 18-29.

HARTMAN, D.S. 1979. Ecology and behavior of the manatee Trichechus manatus in Florida. Lawrence, American Society of Mammalogists, Special publication no. 5, 153p.

HuSAR, S.L. 1978. Trichechus manatus. Mammalian Species, Lawrence, 93:1-5.

Lima, R.P.; D. Paludo; K.G. Silva; R.J. Soavinki \& E.M.A. Oliveira. 1992. Distribuição, ocorrência e status de conservação do peixe-boi marinho Trichechus manatus ao longo do litoral nordeste do Brasil, p. 47-72. In: D. PAludo (Ed.). Peixe-Boi, Coletânea de Trabalhos sobre Conservação e Pesquisa de Sirenios no Brasil. João Pessoa, Ministério do Meio Ambiente/IBAMA, 73p.

Nimer, E. 1989. Climatologia do Brasil. Rio de Janeiro, IBGE, $2^{\mathrm{a}}$ ed., 422p.

REID, J.P.; G.B. RATHBUN \& J.R. WILCOX. 1991. Distribution patterns of individually identifiable West Indian manatees (Trichechus manatus) in Florida. Mar. Mammal Sc., Lawrence, 7: 180-190.

REYNOLDS, J.E. 1981. Behavior patterns in the West Indian Manatee, with emphasis on feeding and diving. Florida Scientist 44: 233-242.

Silva, K.G.; D. PALudo; E.M.A. Oliveira; R.J. SoAvinski \& R.P. Lima. 1992. Distribuição e ocorrência do peixe-boi marinho (Trichechus manatus) no estuário do rio Mamanguape, Paraíba, Brasil, p. 6-19. In: D. Paludo (Ed.). Peixe-Boi - Coletânea de Trabalhos sobre Conservação e Pesquisa de Sirenios no Brasil. João Pessoa, IBAMA, 73p.

WHITEHEAD, P.J.P. 1978. Registros antigos da presença do peixe-boi do caribe (Trichechus manatus) no Brasil. Acta Amazonica 8: 497-506.

Recebido em 12.IV.2001; aceito em 21.II.2002. 